\title{
The subjective use of postural verb in Afrikaans (I): evolution from progressive to modal
}

\author{
Adri Breed \\ Subject group: Afrikaans and Dutch, Potchefstroom Campus, North-West-University, South Africa \\ E-mail: adri.breed@nwu.ac.za
}

\begin{abstract}
A general linguistic use of progressive aspect is to express some kind of subjective meaning. In other words, this aspectual construction is applied to postulate the speaker's attitude towards or emotional involvement with a particular situation. Although this practice occurs in all three Afrikaans progressive constructions, it is clear that the postural progressive in Afrikaans in particular became specialised with respect to subjective expression. The $C P V^{l}$ en construction is even used in constructions that cannot be interpreted as progressive situations (for example, stative or anterior situation types), and furthermore this construction collocates significantly strongly with negative communication verbs (verbs like skinder 'gossip', kla 'complain' and pla 'bother'). The subjective use of progressive constructions in Afrikaans has not received much attention to date. In two complementary articles (this article and The subjective use of postural verbs in Afrikaans (II): a corpus analysis of CPV en in Zefrikaans) the development and use of the CPV en as a subjective or interpretative construction, are investigated. Based on a relevant literature review, the purpose of this article is to propose a development route for the evolution of the subjective $C P V$ en construction; and to highlight some typical characteristics of the subjective $C P V$ en construction, on the basis of a pilot corpus study. The modal CPV en construction develops in five phases. During the first two phases, the postural verb is used to express the physical or spatial orientation of the subject. During the third and fourth phases, the postural verb develops into an aspectual auxiliary verb. It is only in the fourth phase that the progressive construction is used in modal contexts. In the last, fifth phase, the progressive meaning of the $C P V$ en construction fades completely and it evolves into a pure modal construction. The subjective $C P V$ en construction is characterised by two typical characteristics: firstly, the construction is mostly used in negative contexts (such as insult, blame, self-reproach or judgement) and secondly, it is mainly used in informal or spoken language. It does not appear frequently in a corpus of written Standard Afrikaans.
\end{abstract}

Keywords: cardinal postural verb, CPV, postural, progressive, modal use, subjective

\footnotetext{
${ }^{1}$ The term CPV refers to cardinal postural verbs "which (commonly) profiles the Agent as assuming one of the [three] cardinal postures when carrying out the activity" (Lemmens 2005: 1). In this article, the four postural verbs sit 'sit', staan 'stand', le 'lie' and loop 'walk' are regarded as CPVs. In most typological literature on postural verbs, loop ("walk") is not regarded as a postural verb, as it is rather a dynamic activity verb. However, as indicated in Breed (2012), loop in Afrikaans has the same semantic features, lexical form and grammatical function as the grammaticalised $C P V$ en progressive, and therefore, in this article it is considered and discussed entirely as a cardinal postural construction.
} 


\section{Contextualisation}

The progressive is a type of imperfective aspectual category indicating that a particular situation is being continued or is in process. Progressive meaning typically applies to dynamic predicates and therefore progressive constructions typically combine with dynamic verbs - in other words, verbs which indicate that the expressed action or activity requires constant input or energy (cf. Comrie 1976: 24; Bybee, Perkins and Pagliuca 1994: 126; Breed 2012: 53-57). In Afrikaans, three periphrastic progressive constructions are found, namely the i) wees besig om te - ('be ...-ing' for example sentence 1); ii) wees aan die /'t- ('be busy ... ing' for example sentence 2); and iii) $C P V$ en progressive ${ }^{2}$ ('CPV and' for example sentence 3).

(1) Frans is al [besig om te] $]_{P R O G . A U X}$ braaiv. $^{3}$

Frans be already busy to INF.PRTCL barbeque 'Frans is already barbequing.'

(2) Toe gaan hy [aan die] PRog.AUX beweV en hardloop weg. then go he on the shiver and run away 'Then he started shivering and ran away.'

(3) Hy [sit en $]_{P R O G . A U X}$ blaai $_{V}$ deur die stapel folio's voor hom. he sit and page through the heap pages before him 'He sits paging through the heap of pages in front of him.'

These three progressive constructions have recently received much attention in linguistic research (cf. Geleyn 2010; Breed 2012; Geleyn and Colleman 2014; Breed and Van Huyssteen 2014, 2015; Breed and Brisard 2015; Breed, Brisard and Verhoeven to appear). The development and use of the constructions are discussed in depth in the above-mentioned publications, and are compared with equivalent constructions in other Germanic languages, especially those in Dutch. It is clear that the Afrikaans constructions have the same origin as other Germanic progressives, and that it fits neatly within the division of Germanic progressive constructions (cf. Lemmens 2015: 7). However, the "alternative uses" of the Afrikaans progressives have not been studied in much detail to date.

Progressive constructions are in the first instance used to express aspectual meaning. Comrie (1976: 3) explains that grammatical aspect presents the different perspectives from which a situation is considered:

As the general definition of aspect, we may take the formulation that 'aspects are different ways of viewing the internal temporal constituency of a situation'.

As mentioned above, the progressive presents a situation as being ongoing or in process. Even a situation that is set in the past can be presented as a progressive (see sentence 4), since the termination of the situation is not included in the view of the progressive construction; unlike sentence (5), for example, where the assumption is that the washing of the laundry had been completed that morning.

\footnotetext{
${ }^{2}$ These constructions will be referred to as the besig, aan die and CPV en progressives.

${ }^{3}$ All Afrikaans examples are taken from the Taalkommissiekorpus (2011), unless stated otherwise (see footnote 6 for more information on this Afrikaans corpus.
} 
(4) I was doing my laundry this morning.

(5) I did my laundry this morning.
(Progressive past tense)

(Non-progressive past tense)

Van Rooy (2006: 37-64) - based on Quirk, Greenbaum, Leech and Svartvik (1985: 209); Biber, Johansson, Leech, Conrad and Finnegan (1999: 475); Huddleston (2002: 165); Williams (2002: 28-29); Fitzmaurice (2004: 134); and Núñez-Pertejo (2004: 35-36) highlights three other common uses of the progressive form, besides aspectual expression.

Firstly it is used to express concurrent events, or situations that take place simultaneously:

One important elaboration has to do with the expression of simultaneous situations, where a verb phrase in the progressive form serves as a kind of temporal frame within which some other event of shorter duration takes place, perhaps interrupting the event expressed by the verb in the progressive form. (Van Rooy 2006: 43)

In example sentence (6) the conjunction terwyl 'while' is used together with the aan die progressive to indicate that two situations - i) the horses being knee-haltered; and ii) Ingi Friedländer and StomTaljaner walking with the dogs to the farmhouse - are taking place at the same time.

(6) Hulle't hul perde hier gekniehalter terwyl Ingi Friedländer en StomTaljaner en they have their horses here knee-haltered while Ingi Friedländer and StomTaljaner and die honde nog aan't opstap was na die opstal.

the dogs still on to walk up been to the farmhouse

'They were knee-haltering their horses here while Ingi Friedländer and StomTaljaner and the horses were still walking to the farmhouse.'

A second use of the progressive strongly relates to the first, namely to provide background information:

This use of the progressive aspect ties in with a more general trend across languages to use the perfective verb forms for the main action that moves the situation forward, while imperfective forms, such as the progressive, provide background information. (Van Rooy 2006: 43)

Sentence (7) is a good Afrikaans example of this use.

(7) Volgens hulle bedoel hy dat die Galasierrs deur die nakoming van die wet according them mean he that the Galatians through the compliance of the law hulleself plaas onder dieselfde vloek as wat Israel op daardie stadium besig was themselves place under the same curse as what Israel on that stage busy been

om te ervaar.

to INF.PRTCL experience

'According to them, he means that the Galatians - through compliance with the law placed themselves under the same curse that Israel was experiencing at that stage.' 
Although this example sentence also portrays situations that take place simultaneously, the besig progressive is used here to place the focus on Israel's situation at a given moment.

The third common use of the progressive is to express a modal, subjective meaning (also see De Wit, Patard and Brisard 2013; De Wit and Brisard 2014). The speaker's attitude or mindset - usually negative - towards a particular situation is emphasised by presenting the situation as progressive. Ljung (1980) refers to this as an "interpretative" use.

Another elaboration of the meaning of the progressive is what Fitzmaurice (2004: 134) calls the use of the progressive to express speaker/writer stance or attitude, specifically the adoption of a non-neutral stance towards the proposition, usually a sense of disapproval or irritation (Quirk et al. 1985: 199), although it may simply be mild disbelief (Williams 2002: 28-9). In a similar vein, Quirk et al. (1972: 92-3) and Biber et al. (1999: 475) identify the extended senses of vividness of description, emotional colouring or emphasis for the progressive construction. (Van Rooy 2006: 43)

Examples of the subjective use of the progressive can be found in the corpus for all three of these Afrikaans progressive constructions (see example sentences 8 to 10).

(8) Hulle is altyd besig om moeilikheid te maak.

they be always busy to troubl INF.PRTCL make

'They are always making trouble.'

(9) Dit is Greller wat die drama vir sy gaste aan die aandik is. this be Greller what the drama for his guests on the exaggerate be 'It is Greller who is exaggerating the drama for his guests.'

(10) Maar nee, nou loop en beskinder julle die arme man agter sy rug. but no now walk and gossip you the poor man behind his back 'But no, now you're gossiping about the poor man behind his back.'

Although all three Afrikaans progressive constructions can be used to indicate the speaker's particular attitude towards a situation, it would seem that Afrikaans-speakers have a specific preference for one of the three progressive constructions in this type of contexts. It seems that the $C P V$ en progressive has become specialised ${ }^{4}$ to a great extent, to express the speaker's opinion, attitude or feelings towards a particular situation. Breed et al. (to appear), for example, indicate $^{5}$ that verbs of negative communication (words like skinder 'gossip', kla 'complain',

\footnotetext{
${ }^{4}$ Hopper (1991) uses the term specialization to refer to a process by which a grammatalising construction shows increasingly less formal variation, with the consequence that it can express more general grammatical meaning, as limitations that were associated with previous forms, are lost. In accordance with the way this term is used by Breed and Brisard (2015), among others, specialisation in this article rather indicates that a competing grammatical construction (for example the $C P V$ en progressive) evolves in a certain way to develop a specific preference for certain word types or collocations (different from the other competing constructions, such as the besig and aan die progressives).

${ }^{5}$ Breed et al. (to appear) conducted a collexeme analysis (cf. Stefanowitsch and Gries 2003) for the three Afrikaans progressive constructions, to measure the association strength between each of the progressive constructions and the lexical verbs associated with it. This analysis enabled them to determine the verb types or categories that prefer collocating with one progressive (e.g. the CPV en) instead of another (e.g. the aan die or besig).
} 
bedel 'beg', skreeu 'shout', spog 'boast' and pronk 'show off') tend to collocate more with the postural progressive than with any of the other Afrikaans progressive constructions.

Furthermore, in the Taalkommisiekorpus ${ }^{6}$ (2011) (Afrikaans Language Commission Corpus) there are also quite a number of examples of cases where speakers use the $C P V$ en construction ${ }^{7}$ to express their strong feelings about a particular situation, even though the event cannot in any way be interpreted as a progressive event. See the following examples, for instance:

(11) Vir wat staan en nooi jy nou die vroumens? Het ek nie genoeg probleme nie? for what stand and invite you now the woman have I NEG enough problems NEG 'Now why did you have to go and invite that woman? Don't I have enough problems already?'

(12) 'Vir wat moes jy nou gaan staan en baklei, Keith,'vra sy sag. 'Kyk hoe lyk jy nou!' for what must you now go stand and fight Keith ask she soft look how look you now 'Why did you have to go and fight, Keith," she asks softly. "Just look at you now!'

(13) Jy staan en vra nog?

you stand and ask still

'Do you even need to ask?'

(14) Wat met jaloersheid die kollegas in Brittanje, Australië en die Midde-Ooste sit en what with jealousy the colleagues in Britain Australia and the Middle East sit and beny terwyl ons pasiënte tevergeefs om hulp roep en op die vloer in pyn rondkruip. envy while our patients in vain for help call and on the floor in pain crawl around 'Who sit here envying the colleagues in Britain, Australia and the Middle East while our patients are calling for help in vain and crawling about in pain on the floor.'

Sentences (11) and (12) are examples of completed situations with a result that is still relevant to the present, and should in fact be interpreted as anterior aspect ${ }^{8}$. $V r a$ 'ask' in sentence (13) is an example of a telic ${ }^{9}$ verb and sentence (14) is an example of a stative situation ${ }^{10}$. Thus,

\footnotetext{
${ }^{6}$ This Afrikaans corpus was compiled by the Taalkommissie van die Suid-Afrikaanse Akademie vir Wetenskap and Kuns (Taalkommissie 2011). This stratified, synchronic corpus of written Standard Afrikaans consists of about 60 million Afrikaans words. It comprises a variety of written texts, namely prose texts (approximately 6 million words), academic texts (approximately 24 million words) and non-fiction, non-academic texts such as newspapers, magazines and books (approximately 27 million words).

${ }^{7} \mathrm{CPV}$ en construction is used as a term to refer to the formal use of the postural auxiliary verb linking the binding particle en 'and' to the main verb, while $C P V$ en progressive refers to the grammatical construction expressing aspectual meaning.

${ }^{8}$ Anterior aspect, or the perfect, is a type of perfective aspect indicating that some completed situation still has a lasting effect (a condition) as a result. Comrie (1976: 56) gives the prototypical definition of anterior aspect as "the continuing relevance of a previous situation".

${ }^{9}$ Telic situations are situations with an inherent terminal point, which can or will eventually end and cannot be repeated (Comrie 1976: 44). Thus, a situation like Hy maak ' $n$ stoel 'He is making a chair' is telic, because the situation will be over once the chair has been completed and cannot be repeated. In contrast, a situation type such as Hy loop in die straat 'He is walking in the street' does not have an inherent terminal point, and is not described as a telic situation.

${ }^{10}$ States are situation types that do not change by themselves, but require an external agent to bring about change in the condition. Conditions are stable within an undifferentiated period, and the end point of the situation is not included (Smith 1997: 37). Prototypical examples of states are situations described by the verbs glo 'believe', hoop 'hope', vrees 'fear' and ken 'know'.
} 
there are several examples of situation types that are expressed by the $C P V$ en construction, but which are semantically incompatible (cf. Breed 2012: 42-57; Comrie 1976: 7; Bybee et al. 1994: 139-140) with the "ongoing" meaning that is usually associated with the CPV en construction (cf. Kuteva 1999). Based on the examples above, it would therefore appear that progressive connotation of the $C P V$ en construction in this context has faded or completely bleached, and even that the general subjective use of the progressive has evolved to a construction that exclusively expresses subjective meaning, regardless of whether the situation can be progressive or not. When used like this, the $C P V$ en construction should rather be seen as a modal grammatical construction, and no longer an aspectual grammatical construction.

This article takes a closer look at this specialised subjective or interpretative use of the $C P V$ en construction. The purpose of this first article is to describe a development route of the evolution of the subjective $C P V$ en construction, while the aim of the second, subsequent article, namely The subjective use of postural verbs in Afrikaans (II): a corpus analysis of $C P V$ en in Zefrikaans, is to highlight the use of the subjective $C P V$ en construction, based on a corpus investigation of a relevant and appropriate Afrikaans corpus.

\section{The development of the progressive}

As already mentioned, the development of the three Afrikaans progressive constructions is discussed in depth in recent publications (i.e. Breed 2012; Breed and Brisard 2015; Breed et al. to appear). In these publications, however, the development of the Afrikaans $C P V$ en progressive is not presented in terms of Kuteva's (1999) proposed route of development ${ }^{11}$. Since the purpose of this article is mainly to make a theoretical contribution by illustrating the development route of the $C P V$ en progressive towards a modal construction. It makes sense to refine Kuteva's (1999) evolution route in this section, with the main aim to expand it to a development route that also makes provision for this semantic expansion. Therefore, the route of development of the CPV progressive, as suggested by Kuteva (1999), and the phases of development of the Afrikaans CPV en progressive, as suggested by Breed (2012), Breed and Brisard (2015), and Breed et al. (to appear), are reconciled in this section and presented as a typological route for the grammatical evolution of CPVs. The intention is also that this proposed route should be tested in further research for other languages in which a CPV progressive occurs.

Kuteva (1999) studies the evolution of postural verbs to aspectual constructions in a variety of languages, and provides a typological development route for the construction, involving four main phases. The Afrikaans postural progressive is a good illustration of the four phases that are presented by Kuteva (1999: 206-210), and therefore, Kuteva's exposition is illustrated with Afrikaans examples.

\footnotetext{
${ }^{11}$ This development route is specifically presented as a process of grammaticalisation. Grammaticalisation may be described as a process of language change, where a lexical item (for example, a CPV expressing the body posture of a human subject) systematically evolves to a grammatical construction (for example, a postular auxiliary periphrase to express progressiveness). The theory of grammaticalisation is discussed in depth in, among others, Breed and Van Huyssteen (2015), and will is also be presented in The subjective use of postural verb in Afrikaans (II): a corpus analysis of CPV en in Zefrikaans. Therefore, grammaticalisation is not discussed further in this article.
} 


\subsection{Phase I - Physical orientation of a human body}

In the first, or literal phase, the postural verb is used to express the physical orientation of a human body, for example in sentences (15) and (16).

(15) Pieter sit op die bed. ${ }^{12}$

Pieter sit on the bed

'Pieter is sitting on the bed.'

(16) Hy sit by die tafel en lees koerant.

he sit at the table and read newspaper

'He is sitting at the table and reading the newspaper.'

In this first and the second phase, the CPV is used primarily as a main verb.

At the first stage, 'sit'/'stand'/'lie' are used with human subjects to specify the orientation of the human body in space. Note that apart from this specifying meaning, 'sit'/'stand'/'lie' also involve inherent stative semantics, or temporal 'unboundedness' of the verb situation. At this stage 'sit'/'stand'/'lie' can also be used in a coordinate biclausal structure where the second clause denotes a simultaneous verb situation, with a coreferential subject. The subject is marked only once, with the first verb occurring in the sequence, that is, with the postural verb. (Kuteva 1999: 206)

\subsection{Phase II - Spatial orientation of physical objects}

In the second phase the postural verb is used to express the spatial orientation of physical objects. Therefore, it still largely corresponds to the use in the first phase of the development route, but the subject is not limited to human or living entities. Example sentences (17) and (18) illustrate this second phase of development in Afrikaans.

(17) Die potplante staan op die stoep. the potplants stand on the porch

'The potplants are standing on the porch.'

(18) Die potplante staan op die stoep en verdroog. the potplants stand on the porch and wither 'The potplants stand withering on the porch.'

Between the second and third phase, a reanalysis takes place that will make it possible for a construction that expresses spatial orientation to develop into an aspectual construction.

\footnotetext{
${ }^{12}$ Example sentences (15) to (18) are my own examples and not taken from any corpus.
} 
Now, on the present analysis, contexts like [17] ${ }^{13}$ are regarded as the locusfor-change where the biclausal structure [Subject+V1('sit'/'stand'/'lie') +adverbial]+and+[Implicit Coreferential Subject+V2] has fused into the monoclausal [Subject+AUX('sit'/'stand'/'lie')+adverbial+and+V]. What facilitates such a reanalysis of the biclausal structure into a monoclausal structure is, I contend, the loss of the specific 'human body' semantics of 'sit'/'stand'/'lie' in contexts like [18]. The feature inherent 'unboundedness' of verb situation (which is only a secondary, nonfocal feature of these verbs at stage I) now becomes a focal feature. It is no great conceptual-semantic leap for a verb with inherent 'unboundedness' as a focal meaning, and a particular postural meaning as a nonfocal one, to come to be felt as a continuative/durative/progressive marker. (Kuteva 1999: 208)

\subsection{Phase III - Aspectual meaning with inanimate subjects}

Therefore, the third phase is characterised by a syntactic organisation where the postural verb has evolved into an aspectual auxiliary verb, and is linked to the (new) main verb with the binding particle en 'and', in the case of Afrikaans, but also in a number of other languages. In this phase, adverbial constructions are no longer added between the postural predicate and subordinate clause predicate, as in example sentences (16) and (18); but rather after the main verb, for example in sentence (20). Breed and Brisard (2015: 21) for example indicate that [CPV en $V_{L E X}$ ] has now acquired the status of a unit; and that passive and past tense participles are therefore placed before the total periphrasis and no longer before each of the verbs (see 19).

(19) Baie motors het tot in die pad ge[staan en wag] om by die pompe many vehicles PST till in the road PST-Stand and wait-PRs to at the petrol pumps uit te kom.

out INF come

'Many vehicles stood waiting up into the road to get to the petrol pumps.'

Kuteva (1999: 208) explains that the construction of this phase is no longer ambiguous - the interpretation of this sentence is now aspectual. She claims that in this phase; however, the subject is limited to inanimate subjects, as in sentence (20).

(20) Die ketel staan en kook op die stoof. the kettle stand and boil on the stove 'The kettle is boiling on the stove.'

\subsection{Phase IV - Aspectual meaning with animate subjects}

In the fourth phase, it is possible for the construction to combine with living subjects, but the ambiguous, concurrent interpretation of the first phase (which can combine with living subjects as well) is not available in this phase, for example in sentence (21).

\footnotetext{
${ }^{13}$ Kuteva (1999: 208) illustrates this with a Bulgarian example sentence (Drexite sedjat v koridora $i$ sa ${ }^{\circ}$ birat prax. - 'The clothes are in the corridor and gather dust. / The clothes are gathering dust in the corridor.'). However, the Afrikaans example sentence can also illustrate this phase, and therefore, an own reference to an example sentence from the article is added in this quote.
} 
(21) Pieter staan en kosmaak voor die stoof. Pieter stands and make food before the stove 'Pieter stands cooking in front of the stove.'

However, Kuteva (1999) does not specify in her article to what extent the posture or spatial orientation of the subject in the final phases of development still has to correspond with what is being implied by the postural verb. It seems that the fourth phase of the development route to postural aspectual constructions can also be divided into several stages.

Breed and Brisard (2015: 7-9), partially based on Lemmens (2005), indicate that the development of the postural progressive (i.e. a postural construction already in the third or fourth phase of the evolution) can be divided into various stages of development.

In Kuteva's (1999) Phase II, the postural verb still expresses a strong lexical meaning. Lemmens (2005: 196) explains that in this phase, complement verbs are typically limited to verbs that express activities that can be performed in the posture that is expressed by the postural verb.

In the first stage in the development of the aspectual construction (i.e. a construction in Phase III or IV); however, the lexical meaning of the postural verb weakens, as explained above, and it reanalyses to an auxiliary verb. During this evolution, the focus of the action shifts to the action expressed by the second main verb, and the postural verb instead expresses a meaning that corresponds with the meaning of 'to be'. Although the function of the postural verb is now to express aspectual meaning, the action being expressed by the main verb can still be performed in the posture or spatial orientation that is expressed by the postural verb. In sentence (22), the subject is thus literally in a sitting posture while reading a book.

(22) Hy sit en lees en sy aandag is vasgevang deur die boek toe sy met die tee inkom. He sit and read and his attention be caught through the book when she with the tea enter 'He sits and reads, and he is absorbed in the book when she enters with the tea.'

In the next stage, the postural meaning of the postural verb begins to fade further, although to some extent it still remains visible or can still be deduced, for example in sentences (23) and (24).

(23) Die gras is droog en die son brand neer en die beeste staan en wag. ${ }^{14}$ the grass be dry and the sun burns down and the cattle stand and wait 'The grass is dry and the sun is blazing and the cattle stand and wait.'

(24) Gevolglikgee hulle makgemaakte plaasdiere ' $n$ mis weens die haglike dinge rondom Hence give they tamed farm animals a skip due to the appalling things around slagpalekondisies en vervoer daarnatoe, maar skroom nie om wildsvleis te slaughterhouse conditions and transport to there but hesitate NEG to venison INF.PRTCL eet nie, afkomstig van 'n bokkie wat rustig staan en wei voordat hy humaan eat NEG coming from a little deer what peacefully stand and graze before he humanely van die gras af gemaak is deur in professionele jagter. from the grass down made be through a professional hunter

\footnotetext{
${ }^{14}$ Sentence example from Breed and Brisard (2015: 8)
} 
'Hence, they avoid tamed farm animals because of the appalling things about abattoir conditions and the transport there, but they do not hesitate to eat game, coming from a deer that grazes peacefully before being humanely slayed by a professional hunter.'

In sentence (23) it is unlikely that all the cattle in the herd are in a standing position in the field. As explained above, staan 'stand' is not used to indicate that the cattle are in a standing position, but rather as a progressive marker that means 'be busy grazing'. Nevertheless, it is likely that most of the cattle are indeed in a standing position (as opposed to lying down or sitting), and this fact is probably the reason why staan in particular was selected as a postural progressive verb (see Breed and Brisard 2015: 8). Likewise, the purpose of staan in sentence (24) is not to indicate the postural stance of the deer, but rather to emphasise that the deer is oblivious to danger while grazing. In addition, it is unlikely that the deer was actually 'standing'. Rather, one would expect that an animal that was grazing, would be slowly walking while grazing. Clearly, the intention of staan in this sentence is not to indicate that the deer is in a "standing position", but rather that it was 'in the process of grazing'. Therefore, the meaning of staan faded and shifted to that of an auxiliary verbal function. However, in this phase a partial lexical meaning of the postural verb is still detectable, since the physical posture is to some extent still visible. For instance, it would not have had the corresponding meaning if staan were replaced by another postural verb, like sit 'sit' - hence, *'n bokkie het rustig sit en wei ('a deer sat grazing peacefully') is not possible in this phase.

In a next stage the postural verb can also combine with verbs expressing situations that cannot necessarily be performed in a specific posture, for example in sentence (25).

(25) Kan so 'n vlam vir weke daar in die veld staan en brand? ${ }^{15}$

kan such a flame for weeks there in the field stand and burn

'Can such a flame be burning in the field for weeks?'

In this context, the flame refers to a bushfire. Because a fire is in the first instance an inanimate, limbless object, and secondly because it constantly moves and changes form, it is impossible to describe a fire as literally being in a standing posture or as having an erect spatial orientation. The canonical meaning of staan is no longer a requirement for the selection of a postural verb in this phase. Loop 'walk' would, then, have been a better choice in this sentence.

In this stage of development, the postural verb became generalised to such an extent that the original lexical meaning has faded completely. In the first two stages of the development of the $V_{A U X . C P V}$ en $V_{L E X}$ collocation to a progressive construction, the locative origin of the postural verb is still visible to a greater or lesser extent. In this final stage of the development of the aspectual construction; however, the postural verb has lost all locative meaning and has completely changed to an aspectual marker. Also see sentence (26).

(26) Maar nee, nou loop en beskinder julle die arme man agter sy rug. but no now walk and gossip you the poor man behind his back 'But no, now you're gossiping about the poor man behind his back.'

${ }^{15}$ Sentence example from Breed and Brisard (2015: 8) 
In this sentence, it is not relevant whether the subject julle 'youpL' are in fact walking (loop) or not. The postural meaning of the loop en construction has completely faded and the construction evolved to being exclusively a marker of progressiveness. The progressive is mainly used here to express the fact that some or other unwanted situation is taking place. It is clear that it is during this last stage of the development of the aspectual construction that it becomes useful in subjective contexts (see again example sentences 8 to 10).

Apart from adding different stages to Kuteva's (1999) four-phase evolution of postural verbs, in this section, I would like to add a fifth phase of development, namely the development of the postural progressive (with modal use) to a full-fledged modal construction.

In Phase IV, the construction still has aspectual meaning, despite the extent to which the meaning of the postural verb has faded, since the situations can still be seen as progressive constructions. In the last stage of development in Phase IV, the progressive constructions can, however, also have subjective uses. Since the construction in this phase can still be regarded as a progressive, it is possible to express the subjective or interpretive semantics by means of other progressive constructions, without changing the meaning or connotative value of the sentence. The subjective example of a CPV progressive provided earlier in sentence (10) (repeated below) could, for example, also be expressed with the aan die (cf. in example 27) or the besig (cf. example 28) progressives, without compromising the subjectivity of the utterance.

(10) Maar nee, nou loop en beskinder julle die arme man agter sy rug. But no now walk and gossip you the poor man behind his back 'But no, now you're gossiping about the poor man behind his back.'

(27) Maar nee, nou is julle die arme man agter sy aan die beskinder. But no now be you the poor man behind his on the gossip 'But no, now you're gossiping about the poor man behind his back.'

(28) Maar nee, nou is julle besig om die arme man agter sy rug te beskinder. But no now be you busy to the poor man behind his back INF.PRTCL gossip 'But no, now you're gossiping about the poor man behind his back.'

\subsection{Phase V - Modal meaning}

In the final, fifth phase ${ }^{16}$ of the evolution, the postural meaning of the CPV verb is no longer evident, and furthermore, the progressive meaning has completely faded. The CPV en construction is now used exclusively to express subjective or interpretive meaning, even in contexts where progressive interpretation is not possible (again refer to example sentences 11 to 14, repeated below). A test for this non-progressive, modal phase is to try to present the sentences by using other alternative progressive constructions. Because the progressive meaning has completely faded in this phase, it is for instance not possible to combine example

\footnotetext{
${ }^{16}$ The development of a construction is gradual, and therefore the placement of subjective postural construction in Phase III or Phase IV is not always clear, and interpretation often depends on the speaker's judgement.
} 
sentences (11) to (14) with other progressive constructions without changing the meaning or connotative value of the sentence. ${ }^{17}$

(11) Vir wat staan en nooi jy nou die vroumens? Het ek nie genoeg probleme nie? 'Now why did you have to go and invite that woman? Don't I have enough problems already?'

\begin{abstract}
*Vir wat is jy (alewig) besig om die vroumens te nooi? for what be you always busy to the woman INF.PRTCL invite 'Why are you (always) inviting that woman?'
\end{abstract}

Sentence (11), as indicated above, refers to a situation that has already been completed - more specifically, a situation that can be classified aspectually as a perfect, and that cannot be interpreted as a progressive action at all. Because the besig construction can only be interpreted as progressive, it is not possible to combine this sentence with the besig construction without losing the perfect meaning. Whereas sentence (11) implies that the woman had already received the invitation, sentence (29) would for example rather imply a context where the woman's name is on the list of invited guests, but the invitations have not yet been delivered or finalised. In addition, the grammaticality of sentence (29) is questionable and an adverb (for example alewig ${ }^{18}$ 'always') probably needs to be added to make this sentence more acceptable, or semantically inconspicuous.

A similar argument applies to sentence (12). Compare the following two sentences:

(12) 'Vir wat moes jy nou gaan staan en baklei, Keith,' vra sy sag. 'Kyk hoe lyk jy nou!' 'Why did you have to go and fight, Keith," she asks softly. "Just look at you now!'

(30) ?Hoekom was jy aan die baklei, Keith? why been you on the fight Keith 'Why where were you fighting, Keith?'

Whereas sentence (12), just like sentence (11), refers to a situation that has already been completed (in other words particularly a non-progressive situation), sentence (30) rather is an example of a progressive past tense situation with a subjective use. Sentence (12) - as a perfect - clearly focuses on the consequences of the fight ("Kyk hoe lyk jy nou!'” - 'Just look at you now!'); but in contrast, the progressive construction in sentence (30) instead focuses on the acting itself. This sentence would, for example, rather be used when the speaker wants to discover the reason for the fight.

Furthermore, as already mentioned, some lexical-aspectual meanings are not semantically compatible with a progressive interpretation, for example telic and static situations. Because

\footnotetext{
17 Although all four examples are likely to be considered as grammatically or semantically acceptable under certain circumstances, sentences (29) to (32) do not have the same meaning or aspectual interpretation as sentences (11) to (13).

18 The adverb alewig 'always' implies that the situation is frequentative. Bybee et al. (1994: 126) and Breed (2012: 75) point out that a frequentative may be considered as a type of progressive. In this situation, where an additional adverb is required to make the sentence more grammatically acceptable, there is still an indication of the application of a progressive to express subjective meaning.
} 
$C P V$ en can also be used in non-progressive, modal constructions, it is perfectly acceptable to use it in sentences with a telic situation type (see again sentence 13) and a static situation type (see again sentence 14), respectively. Because the aan die as well as the besig constructions have a strong progressive meaning, it is not grammatically acceptable to use it in telic or static situation types (see sentences 31 and 32).

(13) Jy staan en vra nog?

'Do you even need to ask?'

(31) *Jy is nog aan die vra? you be still on the ask

?'You're still asking?'

(14) Wat met jaloersheid die kollegas in Brittanje, Australië en die Midde-Ooste sit en beny terwyl ons pasiënte tevergeefs om hulp roep en op die vloer in pyn rondkruip.

'Who sit here envying the colleagues in Britain, Australia and the Middle East while our patients are calling for help in vain and crawling about in pain on the floor.'

(32) *Wat met jaloersheid besig is om die kollegas in Brittanje, Australië en die what with jealousy busy be to the colleagues in Brittian Australia and the Midde-Ooste te beny terwyl ons pasiënte tevergeefs om hulp roep en op die Middle East INF.PRTCL envy while our patients in vain for help cry and on the vloer in pyn rondkruip.

floor in pain crawl around

?'Who are envying the colleagues in Britain, Australia and the Middle East while our patients are calling for help in vain and crawling about in pain on the floor."

\subsection{Summary - The evolution of $C P V$ en from expression of physical orientation to modal interpretation}

Table 1 presents the grammaticalisation route of the postural verb in five phases, partially based on Kuteva (1999: 210).

Table 1: The five phases of the development of the CPV progressive

\begin{tabular}{|l|l|l|}
\hline Phase & Stage & Characteristics \\
\hline I & I & $\begin{array}{l}\text { Bodily posture (monoclausal) } \\
\text { [anim.subj. + V (sit/staan/lê/loop })+ \text { adv.] }\end{array}$ \\
\hline & II & $\begin{array}{l}\text { Bodily posture PLUS simultaneous verb situation (biclausal) } \\
\text { [anim.subj. + V1 (sit/staan/lêlloop })+ \text { adv.] + en }+ \text { [imlic. co-ref.subj. + V2] }\end{array}$ \\
\hline II & I & $\begin{array}{l}\text { Spatial position of objects (monoclausal) } \\
\text { [inanim. subj. + V (canonical sit/staan/lêlloop })+ \text { adv.] }\end{array}$ \\
\hline
\end{tabular}




\begin{tabular}{|c|c|c|}
\hline Phase & Stage & Characteristics \\
\hline & II & $\begin{array}{l}\text { Ambiguity between: } \\
\text { - } \text { spatial position of objects PLUS simultaneous verb situation (biclausal) } \\
\text { [inanim.subj. }+\mathrm{V} 1 \text { (canonical sit/staan/lê/loop) }+ \text { adv.] + en }+ \text { [implic.co- } \\
\text { ref.subj. }+\mathrm{V} 2] \\
\text { en } \\
- \text { Continuative/durative/progressive (monoclausal) [inamin.subj. + AUX } \\
\quad \text { (canonical sit/staan/lê/loop) }+ \text { adv. }+ \text { en }+ \text { V] }\end{array}$ \\
\hline III & $\mathrm{I}$ & $\begin{array}{l}\text { Continuative/durative/progressive (monoclausal) } \\
\text { [inanim.subj. + AUX (canonical sit/staan/lê/loop) }+ \text { en }+\mathrm{V}+(\text { adv.)] }\end{array}$ \\
\hline \multirow[t]{3}{*}{ IV } & $\mathrm{I}$ & $\begin{array}{l}\text { Continuative/durative/progressive (monoclausal) } \\
\text { [anim.subj./inanim.subj }+\mathrm{AUX} \text { (iconic }{ }^{19} \text { canonical or postural } \\
\text { sit/staan/lêlloop })+\mathrm{en}+\mathrm{V}+(\mathrm{adv} .)]\end{array}$ \\
\hline & II & $\begin{array}{l}\text { Continuative/durative/progressive (monoclausal) } \\
\text { [anim.subj./inanim.subj + AUX (indexical sit/staan/lêlloop) + en + V + (adv.)] }\end{array}$ \\
\hline & III & $\begin{array}{l}\text { Continuative/durative/progressive (monoclausal) } \\
\text { [anim.subj./inanim.subj + AUX (symbolic sit/staan/lê/loop) + en + V + (adv.)] }\end{array}$ \\
\hline $\mathrm{V}$ & $\mathrm{I}$ & $\begin{array}{l}\text { Modal (monoclausal) } \\
\text { [anim.subj./inanim.subj + AUX (modal sit/staan/lêlloop })+\mathrm{en}+\mathrm{V}+(\mathrm{adv} .)]\end{array}$ \\
\hline
\end{tabular}

As mentioned above, it is typologically common for a progressive construction to be used to express subjective meaning. Bybee et al. (1994: 129-133) investigate the lexical origin of progressive constructions and identify a typological pattern indicating that one of the most common lexical origins of progressive constructions is constructions with a locative meaning. In other words, progressive constructions are likely to develop from constructions that indicate place or location in their original use. The development of a progressive from locative constructions may probably be ascribed to the meaning connotation of "be in the place of VERBing" or "be at VERBing". The combination with postural words can be translated semantically as "stand VERBing" or "sit VERBing". Given the locative origin of the progressive construction, it is not surprising that this aspectual construction is used to express subjective meaning.

Thus, considering the semantic elements of progressive periphrastic constructions, it appears that the original function of the progressive was to indicate the positioning of the agents in the midst of an activity. This feature seems to be sustained, even in well-developed progressive forms, such as the English progressive. Based on this general phenomenon, progressive constructions are regularly referred to as examples of temporal categories based on locative categories (Anderson 1973; Traugott 1978, as quoted by Bybee et al. 1994: 137). Bybee et al. (1994: 136) identify five elements or meanings of the locative progressive.

\footnotetext{
19 Peirce's (1955) distinction between an iconic, indexical and symbolic sign is applied terminologically to indicate degrees of lexical relationship in the three stages of Phase IV. Iconic refers to the CPV physically resembling the postural position or orientation expressed in the utterance. Indexal refers to a strong correlation with - but not a direct or complete resemblance to - the postural verb used in the utterance. Symbolic refers to the use of a CPV in an utterance where no postural meaning can be derived.
} 
We propose that the original meaning of the progressive construction is 'the subject is located in the midst of doing something'. The function of this locution is to give the location of the subject. As we suggested earlier, it is used at first for activities that imply a specific location for the subject in the activity. Thus the construction contains either explicitly or implicitly the following elements of meaning:
a. An agent
b. is located spatially
c. in the midst of
d. an activity
e. at reference time.

The progressive, as already pointed out, is a kind of imperfective. The imperfective aspect is traditionally defined as an aspect that considers a situation as if from the inside (Comrie 1976: 24). The focus of an imperfective point of view is on the progress or continuity of the process. The start and end points of the situation are not necessarily included in the point of view (Smith 1997: 95). The progressive, as a type of imperfective, focuses on the continuation of the situation - the termination of the situation is therefore not included in the semantic meaning of the progressive.

According to Van Rooy (2006: 44), this internal perspective adopted by the progressive is crucial for the further development of a subjective use of the construction:

The subjective, internal perspective of the progressive aspect is also relevant to this account, as the speaker steps into a situation and gives the hearer an account of it as an ongoing, but incomplete, situation.

A subjective construction implies that the speaker is affected in one way or another by the situation that is expressed. Kranich (2013: 8) explains that these two aspects (firstly the activity about which the speaker has a certain mind-set or attitude, and secondly the speaker's interpretation of or attitude towards the activity) are simultaneously expressed by a subjective progressive:

The speaker first offers an objective description of a situation and then presents her own subjective interpretation of what the situation amounts to. Ljung describes this use as follows: "The A part expresses the observed behaviour, the B part sums up or interprets this behaviour and the predicate used for this summing up or interpreting is invariably put in the progressive."

It is not surprising then that the postural progressive in Afrikaans in particular has started specialising to become the preferred subjective progressive, as it expresses two distinguishable subjective spaces or "locations": i) the speaker presents the situation from the midst of an ongoing, incomplete situation (cf. van Rooy 2006: 44); and ii) the subject is conducting the action from within his or her own body. 


\section{Typical characteristics of the subjective $C P V$ en construction}

The findings of Breed and Brisard (2015) about the verbs with which the CPV en progressive strongly collocates, indicate that the subjective progressive is apparently mainly used in negative contexts. All examples of the subjective $C P V$ en that are found in the Taalkommissiekorpus (2011), may be associated in some way with a negative context, and no neutral or positive contexts can be associated with any of the results that were found.

The construction is used to express interpretations such as blame (for example 33), ridicule (for example 34), accusation (for example 35), sarcasm (for example 36), self-defence (for example 37), remorse (for example 38), revel (for example 39) and cautioning (for example 40). There are also examples of how the construction is used to describe a situation as being negative (for example 41) or to make a negative judgement about a situation (for example 42). Finally, an example was found where the construction is used to make a negative prediction about what may happen in the future (for example 43).

(33) 'Sy het nou ons hele Kersfees gaan staan en spoil,' sê Ockhuis. she have now our entire Christmas go stand and spoil say Ockhuis

" Now she went and spoiled our entire Christmas," said Ockhuis.'

(34) Dis natuurlik ook die rede waarom die mense nou so te kere gaan om glad van it be of course also the reason why the people now so to rage go to even of gekleurde hoendervere blomme te staan en maak.

(Ridicule)

colored chicken feathers flowers INF.PRTCL stand and make

'That is of course why people are now carrying on like this, even to the point of making flowers of coloured chicken feathers.'

(35) Dis omdat jy in my gesig staan en lieg!

(Accusation)

it be because you in my face stand and lie

'It is because you are lying to my face!'

(36) Dis natuurlik 'n romantiese teruggryp na die era van die Sestigers, toe al it be of course a romantic back reach to the era of the Sixties-authors when al wat leef en beef in die Afrikaanse skrywers-establishment vir ' $n$ jaar of wat in that live and tremble in the Afrikaans writers establishment for a year or what in Parys gaan sit en hulle vervies het oor apartheid.

(Sarcasm)

Parys go sit and themselves annoy PST over apartheid

'It is of course a romantic yearning for the era of the Sixties-authors, when all who were breathing in the Afrikaans writers' establishment went to Paris for a year or two, annoyed by apartheid.'

(37) Jy moet 'n professor wees of 'n predikant, en wie was ek, 'n dorpsonderwyser wie se naam you must a professor be or a clergyman and who was I a town teacher whose name nog skaars bekend geraak het en wat sy eie werk staan en uitgee. (Self-defence) not even yet known became have and what his own work stand and publish 'You had to be a professor or a clergyman, and who was I, a small-town teacher whose name had hardly been known and who was publishing his own work.' 
(38) Maar die feit bly staan, as ek nie gaan staan en dodelik verlief raak het op ' $n$ but the fact still stand if I NEG go stand and deadly in love become have on a kind nie, sou ek en jy seker nou getroud gewees het.

(Remorse) child NEG would me and you probably now married been have 'But the fact remains, if I did not fall madly in love with a child, you and I would probably have been married now.'

(39) Nie alvorens hy homself met die skedel staan en vermaak het nie. (Revel) NEG before he himself with the skull stand and entertain have NEG 'Not before he amused himself with the skull.'

(40) Dis tyd dat jy weer vrou vat, maar asseblief, ek vra jou mooi, moenie gaan staan it be time that you again wife take but please I ask you nicely don't go stand en verlief raak op ' $n$ moordenares nie.

(Cautioning) and in love become on a murderess NEG 'It is time that you take a wife again, but please, I beseech you, do not fall in love with a murderer.'

(41) Natuurlik ook my maat hier, maar ek wil nou nie vir Pa en Ma gaan staan en of course also my friend here but I want now NEG for Dad and Mom go stand and omkrap met name nie. (Negative description) upset with names NEG 'Of course also my friend here, but I do want to go and upset Dad and Mom with names now.'

(42) 'Daar is massas woedende mense van die gemeenskap wat kom staan en there be masses furious people of the community who come stand and vinger swaai,' sê hy. (Negative judgment) fingers shake say he "'There are masses of furious people of the community who come and shake their fingers," he says.'

(43) Wel, dis nou natuurlik te sê as Kitte, 'n geswore oujongkêrel, nie gaan well it is now of course INF.PRTCL say if Kitte a sworn bachelor NEG go staan en koue voete kry nie. (Negative prediction) stand and cold feet get NEG 'Well, that is of course if Kitte, a sworn bachelor, does not get cold feet.'

However, even though the $C P V$ en progressive is the preferred Afrikaans progressive for subjective or modal uses, it does not seem to appear frequently in a corpus of standard written Afrikaans. In the Taalkommissiekorpus (2011), only 63 examples of subjective or modal CPV en uses were identified. Furthermore, all of these examples are from texts that are characterised by a 'natural narrative style', such as dialogue in prose texts, letters or blogs. In 28 of the examples, the postural verbs are found in quotes (i.e. sentences which are presented in direct speech) or texts citing the dialogue of characters in a story (for example 44). Three examples were also found where the construction occurs in dialogue of the prose characters quoted in indirect speech (for example 45). Twenty other examples come from prose texts where an internal focalisor is applied to 'narrate' the story events to the reader from his or her 
(the narrator's) perspective, for example in sentence (46). The remaining examples come from texts such as blogs or letters, where the author engages with the reader in a 'conversation' in an informal narrative style (see for example 47).

(44) 'Dat jy darem so ' $n$ dom ding kon doen om jou weer aan Moira te gaan staan en that you at least so a dumb thing could do to you again on Moira INF.PRTCL go stand and verloof,' sê Tant Siena ongeveins toe hy die kombuis binnegaan. (Direct speech) engage say Aunt Siena unfeigned when he the kitchen enter "That you could do such a stupid thing as to go and get engaged to Moira again," said aunt Siena bluntly when he entered the kitchen.'

(45) Uitvoerende sjef ofte nie, hóm kryjy nie in 'n kantoor waar hy geregte executive chef or NEG him get you-SG NEG in an office where he dishes sit en prakseer nie.

(Indirect speech) sit and devise NEG 'Executive chef or not, you will not find him in an office devising recipes.'

(46) G'n wonder Jonty Jack bly daar bo in die berg nie; g'n wonder hy draai sy no wonder Jonty Jack stay there above in the mountain NEG no wonder he turn his rug op dié suf gemeenskap wat ingeteel hier sit en die gewoontes bedryf waarmee back on this dull community what inbred here sit and the habits run with what hulle al jare besig is asof niks ooit verander nie. (Internalfocalisor) they already years busy be as if nothing ever change NEG 'No wonder Jonty Jack stays there high in the mountain; no wonder he turns his back to this thick-headed, inbred community who are continuing the habits here with which they have been busy all these years as if nothing ever changes.'

(47) Moenie alleen in jou klein hoekie sit en swoeg nie.

(Narrative style)

don't alone in your small corner sit and toil NEG

'Don't sit toiling alone in your own little corner.'

Although some features of the CPV (for example that it mainly conveys negative meaning, and that it is typical of spoken or informal Afrikaans) can be identified in the few abovementioned corpus results, it is clear that a corpus investigation must be carried out in an appropriate corpus, such as a spoken Afrikaans corpus or a corpus of texts characterised by informal language. To this end, a corpus investigation of the subjective use of $C P V$ en will be undertaken with an appropriate corpus in the next and related article, The subjective use of postural verb in Afrikaans (II): a corpus analysis of CPV en in Zefrikaans.

\section{References}

Anderson, J. 1973. An essay concerning aspect: some considerations. The Hague: Mouton de Gruyter.

Biber, D., S. Johansson, G. Leech, S. Conrad and E. Finnegan. 1999. The Longman Grammar of Spoken and Written English. Harlow: Pearson. 
Breed, C.A. 2012. Die grammatikalisering van aspek in Afrikaans: 'n semantiese studie van perifrastiese progressiewe konstruksies. Potchefstroom: NWU. [PhD dissertation]

Breed, C.A. and F. Brisard. 2015. Postulêre werkwoorde as progressiewe merkers in Afrikaans en Nederlands. Internationale Neerlandistiek 53(1): 3-28.

Breed, C.A., F. Brisard and B. Verhoeven. To appear. Periphrastic progressive constructions in Afrikaans and Dutch: A contrastive analysis. Journal of Germanic Linguistics [in press]

Breed, C.A. and G.B. van Huyssteen. 2014. Aan die en besig in Afrikaanse progressiwiteitskonstruksies: die ontstaan en ontwikkeling (1). Tydskrif vir Geesteswetenskappe 54(4): 1-18

Breed, C.A. and G.B. van Huyssteen. 2015. Aan die en besig in Afrikaanse progressiwiteitskonstruksies: 'n korpusondersoek (2). Tydskrif vir Geesteswetenskappe 55(2):1-18.

Bybee, J.L., R.D. Perkins and W. Pagliuca. 1994. The evolution of grammar: tense, aspect and modality in the languages of the world. Chicago: University of Chicago Press.

Comrie, B. 1976. Aspect: an introduction to the study of verbal aspect and related problems. Cambridge: Cambridge University Press.

De Wit, A. and F. Brisard. 2014. A Cognitive Grammar account of the semantics of the English present progressive. Journal of Linguistics 50(1): 49-90.

De Wit, A., A. Patard and F. Brisard. 2013. A contrastive analysis of the present progressive in French and English. Studies in Language 37(4): 846-879.

Fitzmaurice, S. 2004. The meanings and uses of the progressive construction in an early eighteenth-century English network. In A. Curzan and K. Emmons (Eds.) Studies in the History of English II: Unfolding Conversations. Berlin/New York: Mouton de Gruyter. pp. 131-73.

Geleyn, T. and T. Colleman. 2014. De progressieve constructies bezig zijn en bezig wees: Een contrastief corpusondersoek Nederlands - Afrikaans. Tydskrif vir Geesteswetenskappe 54(1): 56-74.

Geleyn, T. 2010. De progressieve constructies bezig zijn en besig wees: Een contrastief corpusonderzoek Nederlands-Afrikaans. Ghent: Universiteit Gent [Bachelor Dissertation].

Hopper, Paul. 1991. On some principles of grammaticization. In E. Traugott and B. Heine (Eds.) Approaches to Grammaticalization, Vol. I. Amsterdam: John Benjamins. pp 17-36.

Huddleston, R. 2002. The verb. In R. Huddleston and G.K. Pullam (Eds.) The Cambridge Grammar of the English Language. Cambridge: Cambridge University Press. pp. 72-211.

Kranich, S. 2013. Functional layering and the English progressive. Linguistics 51(1): 1-32.

Kuteva, T.A. 1999. On 'sit'/‘stand'/‘lie’ auxiliation. Linguistics 37(2): 191-213. 
Lemmens, M. 2005. Aspectual posture verb constructions in Dutch. Journal of Germanic linguistics 17(3): 183-217.

Lemmens, M. 2015. Zit je te denken of ben je aan het piekeren? Persistentie in het synchrone gebruik van de PREP- en POS-progressiefconstructies in het Nederlands. Nederlandse Taalkunde 20(1):5-36.

Ljung, M. 1980. Reflections on the English Progressive. Gothenburg: Acta Universitatis Gothoburgensis.

Núñez-Pertejo, P. 2004. The Progressive in the History of English. Munich: LINCOM.

Peirce, C.S. 1955. In J. Buchler (Ed.) The Philosophical Writings of Peirce. New York: Dover.

Quirk, R., S. Greenbaum, G. Leech and J. Svartik. 1972. A Grammar of Contemporary English. London: Longman.

Quirk, R., S. Greenbaum, G. Leech and J. Svartvik. 1985. A Comprehensive Grammar of the English Language. London: Longman.

Smith, C.S. 1997. The parameter of aspect. London: Kluwer Academic.

Stefanowitsch, A. and S.T. Gries. 2003. Collostructions: Investigating the interaction of words and constructions. International Journal of Corpus Linguistics. 8(2): 209-243.

Taalkommissie van die Suid-Afrikaanse Akademie vir Wetenskap en Kuns. 2011. Taalkommissiekorpus 1.1. Potchefstroom: CTexT [Corpus].

Traugott, E.C. 1978. On the expression of spatio-temporal relations. In J.H. Greenberg (Ed.) Word structure. Stanford: Stanford University Press. pp. 369-400.

Van Rooy, B. 2006. The extension of the progressive aspect in BSAfE. World Englishes 25(1): 37-64.

Williams, C. 2002. Non-Progressive and Progressive Aspect in English. Fassare: Schena Editore. 


\section{List of abbreviations}

$\begin{array}{ll}\text { adv. } & \text { Adverb } \\ \text { anim.subj. } & \text { Animate subject } \\ \text { AUX } & \text { Auxiliary verb } \\ \text { CPV en } & \text { Periphrastic postural progressive construction sit/staan/lê/loop en } \\ \text { CPV } & \text { Cardinal postural verb } \\ \text { implic. co-ref.subj. } & \text { Implicit co-referenced subject } \\ \text { inanim. subj } & \text { Inanimate subject } \\ \text { INF } & \text { Infinitive marker } \\ \text { NEG } & \text { Negation marker } \\ \text { PL } & \text { Plural } \\ \text { PROG } & \text { Progressive marker } \\ \text { PRS } & \text { Present } \\ \text { PST } & \text { Past } \\ \text { SG } & \text { Singular person } \\ \text { V } & \text { Main verb } \\ \text { V1 } & \text { First sentinel main verb } \\ \text { V2 } & \text { Second sentinel main verb } \\ \text { VLEX } & \text { Lexical verb (main verb) }\end{array}$

